\title{
Local agreements as a process: the example of local talks in Homs in Syria
}

\section{Rim Turkmani}

To cite this article: Rim Turkmani (2022): Local agreements as a process: the example of local talks in Homs in Syria, Peacebuilding, DOI: 10.1080/21647259.2022.2032941

To link to this article: https://doi.org/10.1080/21647259.2022.2032941
(c) 2022 The Author(s). Published by Informa UK Limited, trading as Taylor \& Francis Group.

Published online: 15 Feb 2022.

\section{$\sqrt{6}$ Submit your article to this journal $₫$}

LIll Article views: 24

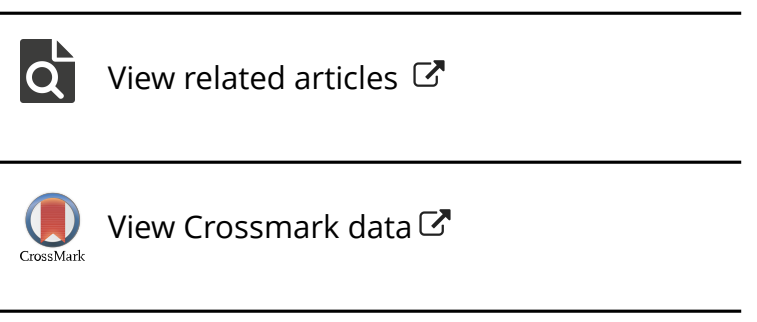




\title{
Local agreements as a process: the example of local talks in Homs in Syria
}

\author{
Rim Turkmani \\ LSE IDEAS, London School of Economics, London, UK
}

\begin{abstract}
This article sets out why it is important to conceptualise local agreements as a process of talks that have a value in their own right rather than as a discrete event reached on a particular date. Throughout this process the terms of intermittently negotiated agreements are continuously shaped by two competing logics, the logic of violence and peace. Based on detailed empirical evidence covering six years of local talks in the city of Homs and its Al-Waer suburb, the article shows that even if an agreement is not reached, the mere process of local talks could lead to a steep reduction in the level of violence, fatalities and an improvement in the standard of living at a time when talks at higher level fail to deliver such results. The article also challenges the main methods of gathering empirical evidence about local peace agreements and discussed potential policy implications.
\end{abstract}

\section{ARTICLE HISTORY}

Received 17 August 2021

Accepted 20 January 2022

\section{KEYWORDS}

Peacebuilding; local peace committees; local ceasefire; Syria

\section{Introduction}

The attention to the 'local' in the peacebuilding literature developed mainly as a response to the failures of the predominant liberal form of peacebuilding, which has largely focused on imposing and realising liberal norms such as state sovereignty, formal institutional structures and the rule of law. ${ }^{1}$ These failures led to a surge of interest in local agency and the 'local turn', driven in part by scholars and practitioners from the global south. Proponents of this trend asked for a reassessment of some of the parameters used by external actors in peacebuilding interventions and to tap into the resources of everyday peace. ${ }^{2}$ Critical inquiries into the merits of liberal peace also contributed to the introduction of new concepts such as hybrid peace in which liberal norms are juxtaposed against local traditional norms and agency with the idea that it is possible to link the two

\section{CONTACT Rim Turkmani r.turkmani@lse.ac.uk}

All research conducted for this article comes under the CRP Syria programme, which has been approved by the LSE Research Ethics Committee, and the approval number is REC ref $000892 \mathrm{~b}$

This article has been republished with minor change. This change do not impact the academic content of the article.

${ }^{1}$ Shahrbanou Tadjbakhsh, Rethinking the Liberal Peace: External Models and Local Alternatives (London: Routledge, 2011).

${ }^{2}$ Roger Mac Ginty and Oliver P. Richmond, 'The Local Turn in Peace Building: a critical agenda for peace', Third World Quarterly 34, no. 5 (2013), https://doi.org/10.1080/01436597.2013.800750.; Oliver P. Richmond and Audra Mitchell, 'Peacebuilding and Critical Forms of Agency', Alternatives: Global, Local, Political 36, no. 4 (2012), https://doi.org/10. 1177/0304375411432099.; and Roger Mac Ginty, 'Everyday Peace: Bottom-Up and Local Agency in Conflict-Affected Societies', Security Dialogue 45, no. 6 (2014), https://doi.org/10.1177/0967010614550899. 
together. $^{3}$ This trend fostered a paradigm shift in the way peacebuilding is conceptualised from following a linear model that assumes that Western 'blueprints' could be imposed upon non-compliant elites' to a non-linear approach anchored in hybridity, local societal processes and practices. ${ }^{4}$

In the last decade, scholars have also started studying local peace-making after a growing number of reports about local peace agreements and truces in conflict zones, such as South Sudan and Syria, captured the interest of policy makers and practitioners. ${ }^{5}$ But with limited academic literature on the topic and with most of what is available on local agreements in the form of grey literature and limited empirical datasets, local agreements are yet to be conceptualised in academic literature.

Local agreements and local mediation were discovered by scholars and practitioners after decades of scholarly and policy work on high-level peace-making and mediation processes. This view has shaped the way local peace agreements are approached in the literature, often judging and measuring them with the same theoretical and empirical tools used to study high-level peace-making, while adding some of the concepts of the local turn in peacebuilding. Local agreements have also been envisioned as positioned at the bottom level of a pyramid that is crowned by a top-level process; and their relevance have been judged by whether and how they can be linked to supporting high-level political talks. ${ }^{6}$ Similarly, the timeline and milestones of local agreements have also been assumed to follow top-level agreements, with a focus on the event of reaching an agreement, usually the date of signing or announcing the agreement (e.g. PA-X local and ETH/PRIO Civil Conflict Ceasefire Dataset). Their impact is judged by developments after that date in the particular locality they are concerned with. ${ }^{7}$

This article draws on rich primary materials in the six-years process of negotiating local agreements in Homs in Syria, including a specially designed innovative crowdbased events database, a database of local agreements in Syria, and interviews with leading local players in the negotiations process. In doing so, it does two things. First, the article challenges the dominant conceptual assumptions about local peace agreements that emphasise the salience of a distinct agreement and the role of such agreements in contributing to top-level peace agreements. What the results demonstrate is that a) even if an agreement is not reached, the mere process of local talks between belligerent parties could lead to a steep reduction in civilian fatalities and improvements to living standards, confirming that b) the significance and relevance of local agreements should not be only seen through the lens of how it supports toplevel processes, but that also that they have a value in their own right that cannot be

${ }^{3}$ Roger Mac Ginty, 'Hybrid Peace: The Interaction Between Top-Down and Bottom-Up Peace', Security Dialogue 41, no. 4 (2010), https://doi.org/10.1177/0967010610374312.

"David Chandler, 'Peacebuilding and the Politics of Non-Linearity: Rethinking "Hidden" Agency and "Resistance"', Peacebuilding 1, no. 1 (2013), https://doi.org/10.1080/21647259.2013.756256.

${ }^{5}$ See for example Dogukan Cansin Karakus of the University of Goettingen and Isak Svensson of Uppsala University, 'Between the Bombs: Exploring Partial Ceasefires in the Syrian Civil War, 2011-2017', Terrorism and Political Violence 32, no. 4 (2020), https://doi.org/10.1080/09546553.2017.1393416.; and Jan Pospisil, Christine Bell, and Laura Wise of the Political Settlements Research Programme, Untangling Conflict: Local Peace Agreements in Contemporary Armed Violence, ASPR, PSRP (2020), https://www.researchgate.net/publication/341708700_Untangling_Conflict_Local_ Peace_Agreements_in_Contemporary_Armed_Violence.

${ }^{6}$ see for example the emphasis on the linkage in the UN literature UN Mediation and Support Unit, UN SUPPORT TO LOCAL MEDIATION: CHALLENGES AND OPPORTUNITIES (DPPA, 2020).

${ }^{7}$ E.g. Karakus and Svensson, 'Between the Bombs.' and Clayton et al., 'Introducing the ETH/PRIO Civil Conflict Ceasefire Dataset'. 
achieved at any other level and that c) a local agreement should not be seen as a discrete event reached on a particular date concerning a particular locality for a limited period. Instead, the agreement is part of a long process of talks that is interlinked to other levels and to other localities, during which the terms of an intermittently negotiated agreements are continuously shaped not only by talks but also importantly, by the exercise of violence against civilians. Second, it challenges the principal methods of gathering empirical evidence about local peace agreements.

The rest of this article is divided into five sections. The first section outlines the current academic debate on local agreements and datasets. Section two presents the sources of the empirical investigations used in this article. Sections three and four present the results of my empirical investigations while section five ends with the discussion and conclusion.

\section{Understanding local agreements}

Local agreements, despite their proliferation, are understudied. The literature is not even conclusive on whether the proliferation of local agreements is a new or old phenomenon. Some argue that they are not new but have become increasingly visible because of the increase in the number of documented, written and publicly available local agreements. ${ }^{8}$ Kaldor et al. argue that they are the natural response to structural shifts in the global landscape of conflict in the post-cold war period which witnessed the emergence of complex and fragmented 'new wars'. ${ }^{9}$ While there is no consensus in the literature on the definition of local agreements, one common feature among most used definitions is the emphasis on a specific local space, even though it is widely acknowledged that they are not isolated from other national and international elements of the conflict. ${ }^{10}$

Given their large number, low profile and discreetness compared to top-level agreements, local agreements are difficult to map and research. Local $\mathrm{Pa}-\mathrm{X}$ is the only available open-access dataset of local peace agreements globally. ${ }^{11}$ It is a sub database of the PA-X peace agreements database developed by the Political Settlements Research Programme. Currently, it provides data on 286 written local peace agreements between 1990 and mid2020 world-wide. The database acknowledges the limitations of mapping local agreements, stating it only includes agreements for which a text was possible to obtain. ${ }^{12}$

Another example of datasets of local agreements is the ETH/PRIO Civil Conflict Ceasefire Dataset, which maps intra-state and non-state conflicts globally between 1989 and 2018. ${ }^{13}$ It covers 338 local ceasefires declarations that have been announced in English-speaking media.

While most of the literature on local agreements relies on case studies or on a few numbers of cases in a particular country, the work of Pospisil is one of the few attempts to study local agreements by looking into a global dataset. ${ }^{14}$ Local PA-X is the main source

\footnotetext{
${ }^{8}$ Pospisil, Bell, and Wise, Untangling Conflict.

${ }^{9}$ Mary Kaldor, Marika Theros, and Rim Turkmani, 'The Introduction to Special Issue', Peacebuilding (2021).

${ }^{10}$ For example Clayton et al, 'Introducing the ETH/PRIO Civil Conflict Ceasefire Dataset', Preprint (2020).; and Pospisil, Bell, and Wise, Untangling Conflict., Kaldor, Theros, and Turkmani, 'The introduction to special issue.'

${ }^{11}$ Peace Agreements Database, https://www.peaceagreements.org/.

${ }^{12}$ lbid.

${ }^{13}$ See more on this database Clayton et al., 'Introducing the ETH/PRIO Civil Conflict Ceasefire Dataset'.

${ }^{14}$ Jan Pospisil, 'Disintegrating Conflict. Local Peace Agreements and Armed Conflict Transitions', Peacebuilding (2021).
} 
of the paper, which explores local agreements by contrasting them against national-level agreements and finds them to be more diverse, shorter, and more issue-focused. It also challenges the established hierarchical way of conceptualising peace and conflict.

The work of Karakus and Svensson on local agreements in Syria draws on a relatively large dataset of 106 local-level ceasefires, compiled from media and NGO reports, that were reached between the years 2011 to $2017 .{ }^{15}$ They conclude that the presence of insider mediators and confidence-building measures are positively associated with successful ceasefire arrangements. They argue that informal and domestic peacemaking should outperform formal and external approaches in managing complex ongoing conflicts. Another example of a study of local agreements in Syria is the study by Turkmani et al. ${ }^{16}$ This study examines more than 35 local negotiations in different parts of Syria, between October 2011 and June 2014 based on 45 interviews. It presents four detailed case studies, three of them written by insiders of the actual local agreements process.

The peacebuilding and peacemaking literature also provide empirical insight into aspects that are related to local agreements such as local dialogue and mediation and their impacts on civilians and communities. Smidt, for example, found that local intergroup dialogue activities help decrease communal violence, drawing its conclusions from a disaggregated dataset of 777 intergroup dialogue activities organised by UN peacekeeping operations in Cote d'Ivoire between 2011 and 2016. ${ }^{17}$ Duursma also draws on event data compiled by the Joint Mission Analysis Centre to support the day-to-day operations of the UN-African Union Hybrid Operation in Darfur between 2008 and 2009. ${ }^{18}$ The dataset includes 199 armed clashes. He finds that the lulls in armed fighting in the $22 \%$ of these clashes that were followed by mediation tend to be significantly longer. The paper concludes that not only are local mediation efforts effective at preventing more armed clashes, but also that peacekeeping staff, especially civil affairs officers, contribute to these mediation efforts.

The use of big datasets to study conflicts has led to critical advances in the way we understand conflict, but it is not without gaps, especially when compared to micro-data. It is argued that big datasets display a strong tendency to record fewer killings than does micro data. ${ }^{19}$ Others emphasise the importance of raising questions as to 'why and how is data being collected and how does the status and position of those collecting the data shape the data and its use'. ${ }^{20}$

I argue that the relevance of data and how it is collected is even more significant in the case of local agreements, the understanding of which often requires local and insider knowledge and insight. Media sources should only serve as a secondary source as part of a mixed methods investigation because of the tendency of media coverage of violent conflict events over peaceful ones in addition to other media biases in

\footnotetext{
${ }^{15}$ Karakus and Svensson, 'Between the Bombs.'

${ }^{16}$ R Turkmani et al., 'Hungry for Peace: Positives and Pitfalls of Local Truces and Ceasefires in Syria', (2014).

${ }^{17}$ Hannah M. Smidt, 'United Nations Peacekeeping Locally: Enabling Conflict Resolution, Reducing Communal Violence', The Journal of Conflict Resolution 64, no. 2-3 (2019), https://doi.org/10.1177/0022002719859631.

${ }^{18}$ Allard Duursma, 'Making disorder more manageable: The short-term effectiveness of local mediation in Darfur', Journal of Peace Research (2020), https://doi.org/10.1177/0022343319898241.

${ }^{19}$ A. Restrepo Jorge, Spagat Michael, and F. Vargas Juan, 'The Severity of the Colombian Conflict: Cross-Country Datasets versus New Micro-Data', Journal of Peace Research 43, no. 1 (2006), https://doi.org/10.1177/0022343306059924.

${ }^{20}$ Roger Mac Ginty, 'Peacekeeping and Data', International Peacekeeping 24, no. 5 (2017), https://doi.org/10.1080/ 13533312.2017.1383561.
} 
highly polarised conflicts. ${ }^{21}$ In the next section, I explain the methodology developed for mapping local agreements in this article and where it differs from other used methods.

\section{Materials and methods}

The arguments in this article draw from empirical evidence from three primary main sources as well as secondary sources. The first source is a novel detailed, microlevel dataset that covers conflict events in Syria on a daily basis between 27/08/2015 and 30/09/2016. It was collected by the Crowd-seeding Conflict and Peace Events in the Syrian conflict project (CCPE). ${ }^{22}$ The project, in which I was involved, aimed at gathering geo-referenced disaggregated data about the Syrian conflict that goes beyond violent events to capture and quantify peaceful events including local agreements. This was motivated by two factors: first that violent events dominate media coverage (and often research interests) at the expense of peaceful events, which remain under-reported and overlooked. The second motivation was driven by the concern that using only media as a source for coding conflict events results in biased data, especially in the context of a highly polarised media reporting landscape in Syria.

CCPE created a database seeded by local researchers based inside Syria. Great attention was paid to the criteria of choosing the researchers to ensure that they did not take part in violence and that their reporting was not tainted by their own political views. The local researchers were provided tailored training on reporting the events, using the platform and best practice in online security. Three main areas in Syria were selected to be covered by the CCPE, including Homs. The local researchers in these areas regularly reported three main types of conflict events: a) violent events, including the type of weapon used, the actors, and the numbers of deaths and injuries among civilians and armed groups, b) peace events, such as events surrounding an agreement to suspend violence, the delivery of humanitarian aid into the area or the restoration of basic services, and c) kidnapping and looting events. Reporting took place through a specially designed secure web-platform which involved a detailed structured questionnaire for each type of event and included the geolocation of the event. Researchers were also asked to provide a descriptive narrative of the event. These descriptions were particularly useful and provided the local narrative surrounding the event and additional rich information that helped explain why the event took place and how it related to other conflict events. No entries in the database were based on media reporting. The nature of reporting to the database, its academic purpose and particularly because it was not aimed at the media, helped in obtaining more independent and honest reporting. $^{23}$

\footnotetext{
${ }^{21} \mathrm{~N}$ Dietrich and K Eck, 'Known Unknowns: Media Bias in the Reporting of Political Violence', International Interactions (2020).

${ }^{22}$ A. S. Rigterink and G. Baliki, 'The Wisdom of Seeking Crowd Wisdom; Reflections on the Ethics of using Crowdsourcing and Crowdseeding to Collect Data in Conflict Zones', Working Paper (2019).

${ }^{23}$ Interview with one of the reporting local researchers.
} 
The CCPE dataset comprises 3,546 reports of events, including 2,639 violent events and 476 'peace events' over more than 400 days. It is the first microlevel dataset covering the Syrian conflict, providing high-frequency of different types of events data. For ethical reasons and because of the sensitivity of the collected data, it is not publicly available and is used only for research purposes.

This article draws only on the data of events taking place in Homs. The data was cleaned, and repetitions were omitted before being used for this article. Reporting of major violent events was also cross checked against their record in the archive of the Syrian Observatory for Human Rights and were found to be very reliable. ${ }^{24}$

The second source is the Local Agreements in Syria Archive (LASA) which I developed over seven years. ${ }^{25}$ The archive traces the process of local talks in each area in Syria and relates it to other conflict events. Considerable parts of the agreements and processes mapped in LASA are produced through the knowledge of people with firsthand involvement in the process. LASA's record of Homs benefits from my direct involvement in the local agreement process, where I played a role supporting and promoting the role of civil society in the talks, and in connecting local mediators with top-level processes and institutions, including the UN. This role gave me an insider understanding of the process and its complexity as well as access to some documents and data. ${ }^{26}$ The full archive of LASA is not publicly available. For the purpose of this paper, I made public the relevant agreements and documents cited in this paper and that do not have security sensitive information.

The third source is eight semi-structured interviews I conducted with some of the mediators of the Homs and al-Waer agreement and the civil society activists close to the process. Two of these interviews were conducted in person in Lebanon in 2014 and 2018 and the rest were conducted over secure VoIP providers between 2014 and 2020.

I present the results of this article in the two following sections. In the next section, I use the empirical evidence from LASA and the interviews to give context to the process of local talks and agreements in Homs up until August 2015. In the section after, I use the CCPE dataset to zoom into the events and developments of 13 months of the conflict and local talks in al-Waer area.

\section{Six years of local talks and agreements in Homs}

The city of Homs was one of the first cities to join the uprising in 2011 and one of the first to kick start a process of local talks and agreements that lasted for six years, beginning in spring of 2011 and concluding in the spring of 2017. In this section, I review briefly the process of local agreements in Homs from 2012 until August 2015 based on the LASA Homs record and the interviews I conducted. There are three key areas relevant for understanding local agreements in Homs, all marked in Map 1. These are the northern countryside, the old city and the suburb of al-Waer.

\footnotetext{
${ }^{24}$ The archive is available at https://bit.ly/3oJf9FC.

${ }^{25}$ Local agreements in Syria Archive (LASA), LASA Homs available at https://doi.org/10.21953/LSE.5RHQLOY7V1PN.

${ }^{26}$ I obtained consent from document owners before using them for this article.
} 


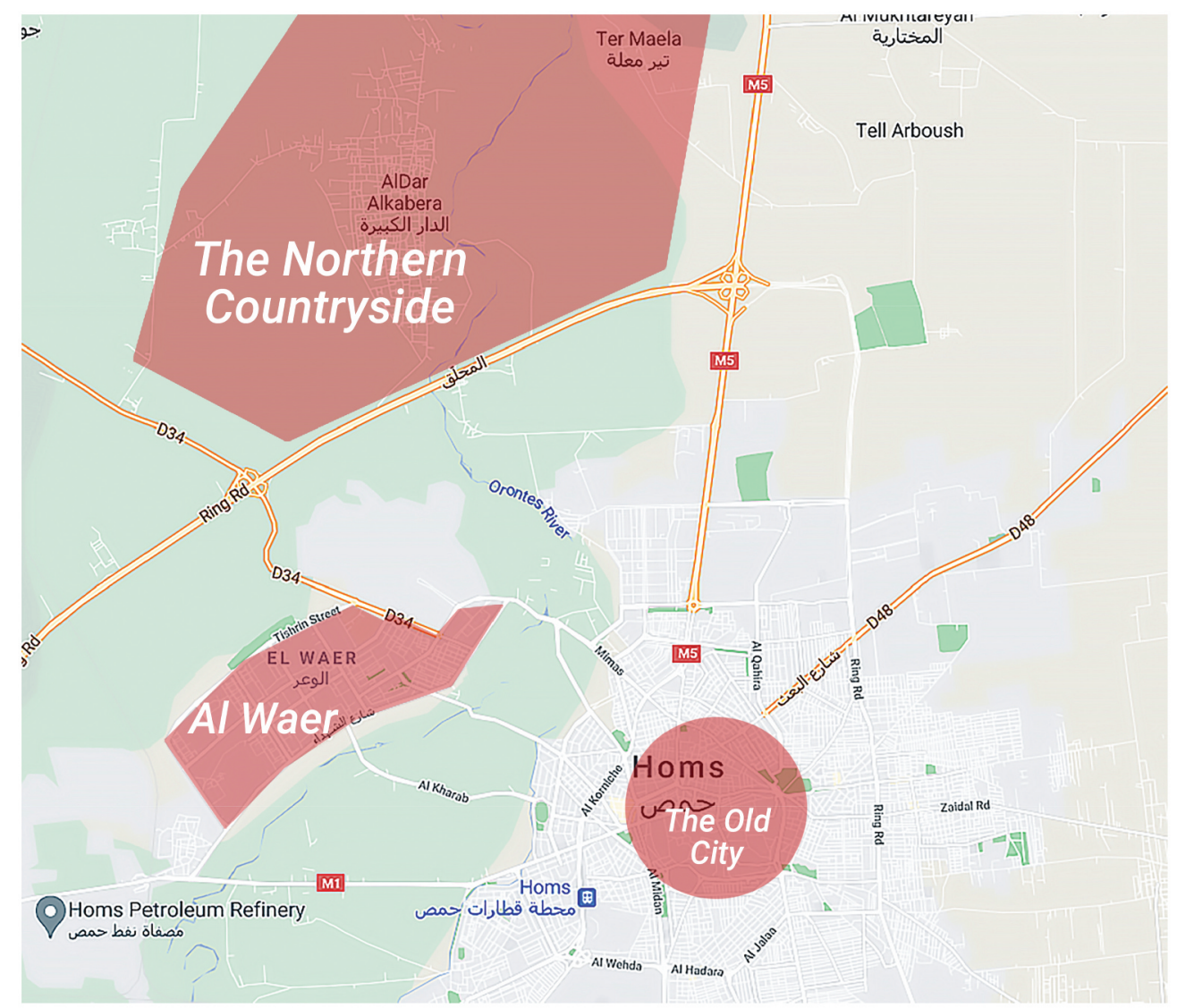

Map 1. The map of Homs showing in red the main three areas that were under opposition-control between mid 2013 and Feb 2017.

As the Syrian conflict became increasingly militarised towards the end of 2011, opposition armed groups, comprised of defected soldiers and civilian volunteers, started forming in different parts of the country. Several formed in Homs and were based in different parts of the city. A series of talks started in February 2012 involving key security and government figures coming from Damascus to conduct talks in Homs. ${ }^{27}$ These talks were constrained by the Syrian army's military campaign launched to take back control of the neighbourhood of Baba Amr, which was under opposition control at that time before the government recaptured it in March 2012. ${ }^{28}$

The failure of this track, combined with other conflict dynamics, contributed to the rapid deterioration of security. The armed-opposition began receiving increased funding and support from abroad, especially from private and state Gulf donors, and was able to extend its security control. At the same time, an increasing number of loyalist militias formed to

\footnotetext{
${ }^{27}$ Interview with a civil society participant of these meetings, August 2014.

${ }^{28}$ 'Battle for Baba Amr - timeline', The Guardian, 1/3/2012, https://www.theguardian.com/world/2012/mar/01/battlebaba-amr-timeline-syria.
} 
help fight the armed opposition and repress public protests. In Homs, loyalist militias fell into two major groups. The first is the National Defence Forces and similar loyalist militias. The second involves the militias recruited from the Shia villages in Homs, mainly al-Rida brigade. ${ }^{29}$ Both groups received training and finance from Iran and Hezbollah.

From the second half of 2013, both al-Waer and the old city of Homs and the northern countryside were under the control of the opposition and therefore under siege and constant attacks by both the government and loyalist militias.

Driven by the stalemate on both the military and the top-level political track, and by the dire situation of civilians, several negotiation attempts took place in 2013. The most prominent was led by a civic committee of doctors and lawyers from Homs with links on both sides. They negotiated a comprehensive framework for a solution in Homs, including both the old city and al-Waer, that would incorporate not only a ceasefire and lifting the siege but also provisions to address local needs. Their first attempt to reach a solution came to an end after top-level meetings in Damascus referred them to Iranian embassy where they were offered what looked like a surrender rather than a deal. ${ }^{30}$ Civilians under siege in the old city were getting very exhausted, and many were unable to wait for the deal for the entire city to be reached. A group of them delegated a small committee to communicate on their behalf with the UN country office asking for help in mediating a deal with the Syrian government that would guarantee safe exit for them out of the siege. In February 2014, a local deal was reached, including a temporary ceasefire during an evacuation of the civilians. 1,348 civilians were evacuated under the supervision of UNHCR and the Syrian Red Crescent, some through a safe corridor from the old city to al-Waer and others to the city itself. ${ }^{31}$ Not all civilians left and the humanitarian situation in the besieged areas continued to be dire as it was expressed in an appeal to the UN by the head of the negotiations committee. ${ }^{32}$

Shortly after, the civic committee of doctors and lawyers restarted attempts to reach a solution for the entire city, refusing initiatives to reach separate deals for each area. This process was interrupted abruptly when another deal, sponsored mainly by regional supporters of the opposition and the government in Homs, was reached for the old city. The agreement, implemented in May 2014, mainly centred on the armed opposition, leaving the old city safely with their light weapons to other opposition-controlled parts in the northern countryside of Homs. This is in contrast to what the civic committee proposed, which is that they remain in the city and go through a disbarment and reintegration process.

At this stage, al-Waer, home to 2,500 members of armed groups and 150,000 civilians, was left on its own. ${ }^{33}$ A new phase of al-Waer-only talks was launched by a new committee of civic and armed actors. Eventually a ceasefire was agreed to on 23 May 2014 but not signed. It included the release of detainees and allowed fighters to travel safely to the northern countryside. After disputes over the implementation timetable, a deal was finally reached at the end of August 2014. Its content included a ceasefire with several humanitarian elements, the release of political detainees and securing the

\footnotetext{
${ }^{29}$ Mohanad Hage Ali, 'The Shi'a Revival', Carnegie Middle East Center (2017), https://carnegie-mec.org/diwan/69819.

${ }^{30}$ Turkmani et al., 'Hungry for Peace.'

${ }^{31}$ For the text of the agreement and the violations during its implementation se LASA Homs, pages 1-3.

${ }^{32}$ LASA Homs, pages 4-5.

${ }^{33}$ The figures are taken from the reports of the neighbourhood committee of al-waer
} 
neighbourhood with a network of checkpoints and a local neighbourhood committee that incorporated local military and civilian personnel. Three weeks later, the negotiations were halted again after disagreements on elements of the agreement and the timetable of implementation. The talks continued on and off, with slow progress and episodes of violence in between. ${ }^{34}$ This is when the period covered by the CCPE database starts and is detailed in the next section.

\section{Daily account of events during local talks}

The CCPE Syrian events database covers the daily developments of events in alWaer neighbourhood for 401 days between 27/08/2015 and 30/09/2016. A total of 280 events entries have been recorded during that period in detail, with some entries summarising the events over one or more days. All the events have been personally experienced or witnessed by the local researchers, or directly communicated to them by members of the neighbourhood or negotiation committees. The recorded events narrative provides further insight to the particulars of the events such as who facilitated or obstructed service and aid delivery, or details of the progress on local negotiations.

During the 401 days period, it is possible to identify three main periods when there was an ongoing process of local talks taking place. These are labelled as P1, P2 and P3. The three periods when local talks were not happening are labelled as V1, V2 and V3. The peaceful and violent periods alternate. In what follows, I give a narrative description of these periods based on the data of the CCPE database.

Table 1 summarises the six periods and the fatalities and causalities in each period in addition to the number of times aid and services were allowed in or restored.

Table 1. The number of people injured and dead in addition to the number of service provision incidents during the six different periods of talks in al-Waer.

\begin{tabular}{|c|c|c|c|c|c|c|c|c|c|c|c|c|}
\hline \multirow{2}{*}{$\begin{array}{l}\text { The } \\
\text { period }\end{array}$} & \multirow[b]{2}{*}{ Dates } & \multirow{2}{*}{$\begin{array}{l}\mathrm{Nr} \text { of } \\
\text { days }\end{array}$} & \multicolumn{4}{|c|}{$\mathrm{Nr}$ of people killed } & \multicolumn{4}{|c|}{$\mathrm{Nr}$ of people injured } & \multicolumn{2}{|c|}{$\begin{array}{l}\text { Delivery of } \\
\text { services and } \\
\text { aid }\end{array}$} \\
\hline & & & Civilian & Armed & Total & Per day & Civilian & Armed & Total & Per day & Total & Per day \\
\hline V1 & $\begin{array}{r}27 / 08 / 2015 \text { to } \\
05 / 10 / 2015\end{array}$ & 39 & 49 & 5 & 54 & 1.38 & 210 & 3 & 213 & 5.46 & 0 & 0 \\
\hline P2 & $\begin{array}{l}06 / 10 / 2015 \text { to } \\
24 / 4 / 2016\end{array}$ & 202 & 8 & 2 & 10 & 0.05 & 24 & 0 & 24 & 0.12 & 16 & 0.08 \\
\hline V2 & $\begin{array}{r}25 / 4 / 2016 \text { to } \\
28 / 5 / 2016\end{array}$ & 33 & 15 & 0 & 15 & 0.45 & 54 & 2 & 56 & 1.70 & 0 & 0.00 \\
\hline P2 & $\begin{array}{r}28 / 5 / 2016 \text { to } \\
28 / 6 / 2016\end{array}$ & 32 & 1 & 0 & 1 & 0.03 & 4 & 1 & 5 & 0.16 & 7 & 0.22 \\
\hline V3 & $\begin{array}{r}29 / 6 / 2016 \text { to } \\
27 / 8 / 2016\end{array}$ & 60 & 17 & 0 & 17 & 0.28 & 82 & 0 & 82 & 1.37 & 2 & 0.03 \\
\hline P3 & $\begin{array}{r}28 / 8 / 2016 \text { to } \\
30 / 9 / 2016\end{array}$ & 34 & & 0 & 0 & 0.00 & 0 & 0 & 0 & 0.00 & 8 & 0.24 \\
\hline \multicolumn{2}{|c|}{$\begin{array}{l}\text { Total for peaceful } \\
\text { periods }\end{array}$} & 268 & 9 & 2 & 11 & 0.027 & 28 & 2 & 29 & 0.09 & 31 & 0.18 \\
\hline \multicolumn{2}{|c|}{ Total for violent periods } & 132 & 81 & 5 & 86 & 0.7 & 346 & 4 & 351 & 2.85 & 2 & 10.01 \\
\hline \multicolumn{2}{|l|}{ Total } & 401 & 90 & 7 & 97 & 0.24 & 374 & 6 & 380 & 0.95 & 33 & 0.08 \\
\hline
\end{tabular}

${ }^{34}$ See LASA Homs pages 7-8 for the drafts of some of the agreements reached during that period. 


\section{First violent period}

The first violent period lasted for 39 days. No local talks were taking place, no peaceful events were recorded and attempts to bring in external support for the local talks had failed. Violence claimed the lives of 54 people and injured 213 others. No cases of any type of services or aid were recorded, while six cases of obstructing the delivery of services to the area were recorded, including looting medical aid vans and barring food deliveries.

Four of the violent events were related to events far from al-Waer and led to the killing of four civilians and the injury of 18 others. They were initiated by Shia militias against the people of al-Waer in retaliation for the siege and violence imposed on the people of two Shia villages in Idleb by other opposition armed groups.

On $26^{\text {th }}$ of September, government forces hit al-Waer with a ground-to-ground missile which landed on a crowded children's fairground on the third day of the celebration of al Eid. $^{35}$ The attack killed 31 civilians and injured 130, mainly children. The scale of what became known as the 'Playground massacre' prompted a return to negotiations.

\section{First peaceful period}

A week after the 'Playground massacre', local talks resumed in Homs after a two-month halt and started the first peaceful period. Immediately after, two spoiler violent events by loyalist militias lead to the death of one civilian and the injury of two others. The narrative of the events noted that these spoiler events sought to protest the resumption of the talks and promises to allow medicine and aid delivery. The talks were upgraded to the Damascus level when, on 9 September 2015 a delegation from the opposition visited the capital for talks with top security officials. As soon as the committee returned to alWaer, attacks on the neighbourhood were launched by Shia militias in another spoiling attempt.

Despite the spoiler violence setback, the talks continued initiating what became the longest stretch of relative calm in al-Waer and a relative easing of the siege which lasted for 202 days. Out of the 102 events recorded during this period, 53 of them were peaceful events, 41 of which were negotiation meetings. Violence killed 10 people and injured 25 others. Sixteen events of major service delivery were recorded such as allowing food and other goods to be regularly delivered, allowing the UN, ICRC and SARC to enter the neighbourhood, deliver aid, meet with locals, and deliver fuel for the first time in three years. Most of the incidents of obstructing service and aid delivery took place when local talks were stuck around the issue of detainees.

After several negotiation meetings, an agreement was reached early December 2015 that was not very dissimilar to the agreement reached in September $2014 .^{36}$ The main difference was the diminished role of the 'neighbourhood committee', now reduced to preparing a list of detainees and kidnapped persons. The agreement's implementation was divided into three phases. It did not include any integration elements for the members of armed groups, many of whom opted to leave al-Waer through a safe corridor to the northern countryside. The first phase of implementation began on 9 December with a ceasefire and the evacuation of 750 members of armed groups. A series of

\footnotetext{
${ }^{35}$ The Syrian Human Rights observatory recorded that 24 people died on the day of the attack: https://bit.ly/3n0a9fl.

${ }^{36}$ LASA Homs, pages 9-10.
} 
explosions in the Alawite majority neighbourhood of al-Zahra followed on the $12^{\text {th }}$ and the $29^{\text {th }}$ of December and killed tens of people. This delayed implementation, but the ceasefire continued with minor violations, mainly committed by al Rida Brigade.

On the $2^{\text {nd }}$ of January 2016, the government and the opposition delegation met and agreed to start the implementation of the agreement's second phase. Shortly after, the head of the opposition negotiation committee survived a kidnapping attempt by masked gunmen. The second phase of implementation started with the delivery of fuel, food and other goods now allowed regularly into al-Waer. The government took steps to restore civic services in the neighbourhood. Progress on implementation stumbled when yet another explosion in the neighbourhood of al-Zahra took place on the $24^{\text {th }}$ of January. A meeting with the opposition delegation was postponed and food delivery was blocked. When talks resumed, government security officials appeared to back away from some promises made in the agreement, particularly the release of detainees. A few violations to the agreement followed, but the level of violence remained low.

In a negotiation meeting on the 4 th of March, government officials requested fastforwarding the implementation of the agreement to phase three, even though the second phase was not fully implemented. The biggest issue was the release of 7,000 detainees requested by the opposition. Government officials argued that this could only happen after all the members of armed groups had left al-Waer. But the opposition refused to move to the third phase before the release of the detainees.

\section{Second violent period}

Violence immediately resumed on 25 April 2016 as talks broke down. It lasted for 33 days of nearly all violent events, killing 15 people and injuring 56 others. Five incidents of obstructing service delivery were recorded, including not allowing the UN and ICRC to deliver aid. Not one incident of service delivery was recorded, and no negotiation meetings took place. On the $27^{\text {th }}$ of May, the government forces targeted al-Waer with several ground-to-ground missiles leading to the death of 13 people. This prompted again a return to negotiations.

\section{Second peaceful period}

The second peaceful period started when negotiations resumed, and a truce was announced at the end of May 2016. It lasted for 32 days. A total of 39 events were recorded during that period, 11 out of which were peaceful events including substantial aid delivery by the UN and SARC and no incidents of services obstruction. Four negotiations meetings were recorded, one of which was with UN officials including the country representative of the UN special envoy to Syria. They discussed UN attempts to support the ongoing talks and the delivery of aid.

After the announcement of a ceasefire, government officials invited the opposition negotiations committee for a meeting at a checkpoint on the outskirts of al-Waer. There they were all arrested and taken hostage by the government. Their release was conditioned on the opposition allowing the safe evacuation of some government army officials stationed at the Charity Hospital inside al-Waer. The exchange took place on the same day and the committee was released. 
With this breach of trust, the government sent a new mediator to al-Waer, Sheikh Mahmoud al-Fadous, a local tribal leader. He met with the negotiations committee, who reiterated their refusal of any solution that included the evacuation of all armed opposition and did not include the release of detainees. After several communications, they rejected his mediation, giving the following reasons: a) that he asked the opposition to compromise on the issue of detainees, b) that his son was very close to the regime and to Iran, and c) because they hoped that the ongoing attempt by the armed opposition in the northern countryside to expand its military control to reach al-Waer might succeed and end the siege by linking al-Waer to the countryside. An interview I conducted with an insider of the talks from the opposition side confirmed the accuracy of the reasons given above to the rejection of the mediation initiative. ${ }^{37}$

\section{Third violent period}

A new episode of violence soon started after the rejection of al-Fadous mediation initiative. It lasted 60 days during which 56 events were recorded, only three of them peaceful events. During this period, 17 civilians were killed and 82 injured. Two incidents of service delivery were recorded and another two incidents of service obstruction. In general, the siege tightened during that period and violence was used intermittently on a low scale until the area was hit by an aerial attack on the $27^{\text {th }}$ of August, killing 12 civilians and injuring 20 . Once again, the surge in violence prompted a return to the talks.

\section{Third peaceful period}

The final peaceful period started on 28 August 2016 when talks resumed again and a ceasefire was announced for two days during which the opposition was asked to consider a new offer which included the release of 200 detainees and the disclosure of the status of other detainees. $^{38}$ The offer was accepted; the ceasefire was extended, and 194 detainees were released. No civilians or armed men were killed or injured during that period, and 8 incidents of service and aid delivery were recorded, including substantial aid delivery by the $\mathrm{UN}$, and only one incident of service obstruction. Six negotiations meeting took place.

The evacuation of around 1,000 people, including fighters, to Idleb was meant to follow, but was delayed because the government asked the UN to take part in implementing the evacuation. The UN refused to play that role because they did not want to be seen as part of displacement plan. On 21 September, the evacuation started with 500 civilians and 250 armed fighters.

Although the CCPE database record of this period ends on 30 September 2016 the record of the LASA shows it lasted longer. Despite the evacuation of some fighters, the armed opposition remained in control of al-Waer and many civilians still feared being subject to arbitrary arrest should government forces enter the area. At this stage, Russian officials became involved in the talks. They rejected attempts by the opposition committee to restart talks based on the August 2016 agreement, the implementation of which had stalled due to the failure to release the detainees. The talks then collapsed and immediately

\footnotetext{
${ }^{37}$ Interview with a member civil society who was very close to the talks, August 2017

${ }^{38}$ LASA Homs, pages $11-13$.
} 
after, a very intense military campaign against al-Waer began between 8 of February and 8 March 2017. During this campaign, at least 55 civilians were killed, more than 200 were injured and substantial destruction was caused by aerial campaigns. ${ }^{39}$ This led to severe pressure on the opposition negotiating committee to go back to the talks the first week of March 2017. After several meetings and several drafts, a final agreement formula was reached on 13 March 2017. The agreement was implemented and around 20,000 people, $66 \%$ of them are women and children, ${ }^{40}$ were evacuated over a few months to the northern countryside of Aleppo.

To complement the picture about the development of the talks and the motivations behind engaging or end the talks, I conducted further interviews with three civil society insiders. ${ }^{41}$ I present their views here. On whether the issue of detainees was always the core issue that led the opposition to end talks, they explained that the opposition actually knew well that the government would not release the detainees or release only few. And while the issue of detainees was indeed an important one, the opposition often used often used it to shift blame for not reaching an agreement on the government and to reduce public pressure on themselves. They provided two main reasons as to why the armed opposition at times avoided concluding an agreement with the government. First, they always hoped that military advancement from the northern countryside would take place and link alWaer to other opposition-controlled areas, and that these hopes kept being inflamed by battles initiated in the northern countryside with support from the Gulf. Second, the opposition hoped that the question of the future of Homs would be included and settled in one of the top-level talks. They requested track one actors several times to incorporate Homs in top-level talks. For example, they wrote a letter to the UN special envoy to Syria saying, 'We are writing to you to ask you to work on and ensure that Russian and the United States included al-Waer area in the Cessation of hostilities agreement that they reached so that this area is protected from shelling and violence'. ${ }^{42}$ But when extreme violence was used, the opposition found no other available immediate option to end the bloodshed except engaging in local talks and forgetting about external solutions.

\section{Discussion and conclusions}

The detailed account of local talks in Homs re-affirms the many merits of local mediation and talks discussed in literature. But it also provides a deep insight on some of the aspects of these talks and raises several questions and issues which I discuss here.

\section{Effects on Everyday Life}

When comparing the figures of the peaceful and violent periods in Table, a very stark image emerges. During the peaceful periods when local talks were ongoing, people were 26 times more likely not to be killed and 31 times more likely not to be injured as a result of violence. Service restoration and aid delivery were 16 times more likely to take place. In

\footnotetext{
${ }^{39}$ The records of the Syrian observatory for human rights, available at https://bit.ly/374SGgf, also include similar figures

${ }^{40} \mathrm{~A}$ report from al-waer neighbourhood committee which oversaw the evacuation.

${ }^{41}$ Interview with three members of civil society from Homs.

${ }^{42}$ Private communications
} 
other words, when local talks take place, even when a final agreement is not reached, there was a substantial improvement to the lives of the civilians in terms of reducing violence, the likelihood of death and injury and to the quality of life itself.

What also emerges when comparing the numbers of deaths and causalities in all periods between civilians and armed men is that civilians are $93 \%$ more likely to be killed and $98 \%$ more likely to be injured than armed men.

These results suggest that the significance and relevance of local agreements should not be only seen through the lens of how it supports the top-level process. They also have a value in their own right that cannot be achieved at any other level. Indeed, the results show that, at times, waiting for the Godot of progress at top-level talks could lead to setbacks in local talks as it reduces the motivation to reach a settlement on the ground.

\section{To talk or not to talk}

In the three examples of talks starting after long pauses in periods P1, P2 and P2, the prompter for talks was the sudden and excessive use of violence against civilians by formal government forces using either missile or aerial attacks. This was consistent with the rest of the evolution of local talks in Homs, such as the excessive use of force in September 2015 and February 2017. Other talks, such as the old city one through the UN, were motivated by a genuine desire to end the suffering of the civilians.

What brought an end to the talks and the beginning of violence? In V1 and V2, violence started after the opposition reported that the regime was refusing to release the detainees as promised. The onset of V3 also was partially related to the question of detainees but additionally involved another issue that made the opposition reject returning to the talks. They had hopes that a solution may come from outside the area, either in the form of military advances by the opposition from the northern countryside or in terms of an international solution.

What becomes clear from the flow and narrative of the events is that throughout the local talks process, two competing logics were at play: the logics of violence and peace. The logic of violence was mainly, but solely, driven by armed and security actors and the political leaders who believed that they can only leverage talks through violence, while the logic of peace was mainly promoted by civic actors and some leaders of armed actors who believed that a military solution would be costly and/or not viable. These competing logics existed on both sides of the table. In the latter logic, both UN pressure and the role of civilians is significant. Even if the former logic predominates, the talks bring some benefits for civilians.

\section{Local agreements or local talks process?}

The results of this article raise a number of questions around the way in which local agreements are conceptualised and the methodologies used in mapping them. The results show that local agreements were not simply local contracts agreed by belligerent parties on a particular date for a narrow period of time. Nearly all the local talks and agreements in Homs over six years relate to one another and were part of one long process that is linked to events at the national and international levels. Within this process, the terms of an intermittently negotiated agreement were continuously shaped not only by mediation and talks but also by the exercise of violence against civilians, arbitrary arrest and 
deprivations of the freedom of movement, food and basic services. Importantly, the marker date for the beginning of a ceasefire and easing of the siege was not the date of reaching an agreement, but the date of the beginning of talks.

\section{Capturing local processes}

The above calls for a revisit to how local agreements are mapped and interpreted. First, there is the question of the use of media as a source for gathering information about local agreements, especially in a second language. ${ }^{43}$ Reliance on English-speaking media as a source may be a good start to provide an initial indication that agreements are being forged but more in-depth research would be needed to capture the full scale, depth and context of these agreements. Many of the informal talks and agreements that led to ceasefires in the case of Homs were usually not reported in the Arabic media, let alone English-speaking media. Another example is the erroneous assumption made in a paper on local ceasefires in Syria which states that they were promoted in 2014 by 'prominent conflict resolution practitioner Nir Rosen and White House National Security Council member Robert Malley' leading to the UN Special envoy to Syria, De Mistura, adopting this approach, all based on a report that was leaked to the media. ${ }^{44}$ The assumption not only ignores the fact that local talks and ceasefires were taking place in Syria since 2011 and driven, at that time mainly by local demand and initiatives, but it also denies the locals their agency. As demonstrated above, locals in Homs initiated ceasefire talks themselves and reached out to the UN for help even before De Mistura was appointed. After his appointment, many letters were written to him from civic leaders in Homs asking for UN assistance in the local talks that they initiated.

Second, even when agreements did feature in the media, it is necessary to frame them in the context of the local talks that led to them in order to effectively evaluate their impact. For example, if one were to evaluate the $4^{\text {th }}$ of December 2015 agreement which featured in the media and in PA-X local without situating it within the history of the process of talks preceding it, one might conclude that the ceasefire announced in this agreement lasted only for ten days, as stated in its first article, and that it started only after signing the agreement. But as the results in this article show, this agreement was not new and was never signed. It was a reiteration of a previous agreement with some changes. The actual ceasefire associated with this agreement started two months earlier when the talks began and lasted for around four months. Its terms were not fully implemented but became themselves the subject of new negotiations before the agreement re-emerged again in a new iteration.

The results also show that the crowd-based method has strong potential in gathering the genus of granular, reliable data required for understanding local processes. This is especially the case if it provides the space for local researchers to log in their knowledge of what is happening around them based on how they experience it and not to limit their role by only ticking pre-defined answers. Through them, the local could be seen through local eyes, and not observed from the outside through what makes its way to the media. Mapping both peaceful and violent events is also critical for understanding of conflict dynamics and how they relate to each other, as opposed to mapping only violent events that is followed by most

\footnotetext{
${ }^{43}$ This is a methodology used by which is used by the ETH/PRIO Civil Conflict Ceasefire Dataset

${ }^{44}$ Marika Sosnowski, 'Reconciliation Agreements as Strangle Contracts: Ramifications for Property and Citizenship Rights in the Syrian Civil War', Peacebuilding 8, no. 4 (2019), https://doi.org/10.1080/21647259.2019.1646693.
} 
conflict databases. Crowdseeding indeed comes with its own difficulties, as it requires carefully choosing, training and monitoring local researchers while also raising new ethical challenges. ${ }^{45}$

\section{Implications for policy}

Finally, for the interest of policy making and designing external interventions to support local peace-making, the results of this article suggest that in the investigations of local mediation, it is very important to map and understand the mediation attempts that failed, and not only the ones that succeed. Understanding why they failed and what could have been done to support these initiatives could help more informed policy making.

The experience of Syrian-driven mediation in Homs, for example, shows that the local mediation initiatives that had the hallmark of what it takes to achieve a durable peace, were the ones that actually failed. Such agreements included addressing local grievances and opting for disarming and re-integrating fighters, or enrolling them in local policing units, rather than dislocating them to become a fuel for violence in another locality. Civic leaders and civilians found themselves marginalised by armed actors on all sides and struggled to get much needed support and protection from the UN, which the government tried to limit its role for the implementation of its own agreements. They also saw their efforts being sabotaged by external partisan actors, an issue which I explore further in another related paper. ${ }^{46}$

It is important also to note that the failure in agreeing protection mechanisms for civilians during local talks forced many of them to choose being displaced from the area to seek safety.

When the UN was allowed a minimum intervention space, it was able to protect civilians, improve humanitarian conditions and to offset somewhat the negative impact of external partisan actors. Critically, the lack of a formal mandate to enable the UN to play a role in local talks prevented it from being able to assert its role against the rejection of the Syrian government. The result of marginalising civilians was agreements geared mainly for the interests of armed actors and the partisan external actors. A greater multilateral presence could have strengthened the role of civil society, protected civilians, and kept the locally initiated civic-led process alive.

\section{Disclosure statement}

No potential conflict of interest was reported by the author(s).

\section{Funding}

This work was supported by the Carnegie Corporation of New York [G-18-55718].

\section{Notes on contributor}

Dr. Rim Turkmani is a senior policy fellow at LSE IDEAS and is the principal investigator of the research project Legitimacy and citizenship in the Arab world project.

\footnotetext{
${ }^{45}$ Rigterink and Baliki., 'The Wisdom of Seeking Crowd Wisdom'

${ }^{46} \mathrm{R}$ Turkmani, 'How Local are Local Agreements? Shaping Local Agreements as a new form of Third-Party Intervention in Protracted Conflicts', Peacebuilding (2021). Submitted.
} 